\title{
Sickle Erythrocytes, after Sickling, Regulate the Expression of the Endothelin-1 Gene and Protein in Human Endothelial Cells in Culture
}

\author{
Michael Phelan, Susan P. Perrine, Mark Brauer, and Douglas V. Faller \\ Cancer Research Center, and Departments of Medicine, Biochemistry, Pediatrics, Microbiology, Pathology and Laboratory Medicine, \\ Boston University Medical Center, Boston, Massachusetts 02118
}

\begin{abstract}
The molecular defect in sickle cell disease resides in the $\beta$ globin gene, with consequent defects in erythrocytes only, suggesting that the vascular occlusion and vasomotor instability which characterize this disease are the result of interactions between abnormal sickle erythrocytes and cells of the blood vessel wall. We explored whether sickle erythrocytes may have effects on vascular tone, exclusive of adhesion events. Exposure of human endothelial cells in culture to previously sickled sickle erythrocytes resulted in a four to eight-fold transcriptional induction of the gene encoding the potent vasoconstrictor endothelin-1 (ET-1). Unsickled sickle erythrocytes or normal erythrocytes exposed to "sickling" conditions had no effect on ET-1 gene induction. Contact of the sickled erythrocytes with the endothelium was not required. Elevations in the ET-1 transcript peaked at 3 $h$ after exposure and persisted for up to $24 \mathrm{~h}$. Four to sixfold increases in the amount of ET-1 peptide was released into the medium surrounding the endothelial cells after exposure to sickled sickle erythrocytes. This is the first demonstration of the regulation of gene expression in endothelial cells as a result of interaction with sickle cells, with induction of genes encoding vasoconstrictors. Furthermore, these findings suggest that sickle erythrocytes may have the capacity to affect local vasomotor tone directly. (J. Clin. Invest. 1995. 96: 1145-1151.) Key words: hypoxia • vasoconstrictor • umbilical vein - gene regulation - platelet-derived growth factor $B$
\end{abstract}

\section{Introduction}

Sickle cell disease is characterized by vasoocclusive events, which may occur in a wide range of vessels, ranging from the microvasculature to the muscular arteries (1-5). Although the most severe morbidity of the disease results from vascular damage, the molecular defect in sickle cells disease is in the $\beta$ globin

Address correspondence to Douglas V. Faller, Cancer Research Center, Boston University School of Medicine, 80 E. Concord Street E124, Boston, MA 02118. Phone: 617-638-4173; FAX: 617-638-4176.

Received for publication 23 December 1994 and accepted in revised form 18 May 1995.

J. Clin. Invest.

(c) The American Society for Clinical Investigation, Inc.

0021-9738/95/08/1145/07 \$2.00

Volume 96, August 1995, 1145-1151 gene, with direct consequent changes only in erythrocytes. This raises the possibility that the vascular occlusion and vasomotor instability which characterize sickle cell disease are the result of interactions between these abnormal erythrocytes and the blood vessel wall. Most investigations on such potential interactions have examined mechanisms which may mediate adhesion of sickle erythrocytes to endothelium. There is also evidence, however, to suggest that sickle erythrocytes may have direct or indirect effects on vascular tone, exclusive of adhesion events. Sickle erythrocytes have been shown to interact with human endothelial cells: they adhere to endothelial cell monolayers $(6-8)$, stimulate prostacyclin release (9), and inhibit human venous and arterial endothelial DNA synthesis (10).

The overall tone of the vasculature is the result of a dynamic and shifting balance between stimuli provoking contraction and relaxation. Local mechanisms are the most likely to be adversely affected in sickle cell disease. The vascular endothelium is the major source of paracrine effects on the contractile elements of the blood vessel (11). The endothelial cell layer forms the permeability barrier between circulating blood cells and the underlying vascular tissue, which is composed of fibroblasts and smooth muscle cells. As such, it is in a unique position to respond to circulating factors or blood elements and modulate events in the vasculature via paracrine effects. Endothelin-1 $(E T-1)^{1}$ is a powerful vasoconstrictive agent released by endothelial cells (12). ET-1 is rapidly cleared from the circulation, but has a long-lasting local effect on vascular tone. Physiological responses to endothelin are reported for blood vessels derived from a large variety of tissues including the heart, kidney, and brain (13). Factors shown to induce ET-1 production by endothelial cells include thrombin (14), transforming growth factor $\left(\operatorname{TGF}_{\beta}\right)$, shear stress $(12,15)$, and hypoxia $(16,17)$. ET-1 is thought to act locally, but elevated circulating levels of this peptide have now been reported in subjects with sickle cell disease in preliminary studies $(18,19)$.

We demonstrate here that the interaction of sickle erythrocytes, after sickling, with human endothelium in culture results in the transcriptional activation of the preproendothelin-1 (preproET-1) gene. Sickle erythrocytes which have not undergone sickling in vitro do not induce the gene. This is the first demonstration of the induction of genes in endothelial cells as a result of interaction with sickle cells.

\section{Methods}

Cell culture. Primary cultures of human umbilical vein endothelial cells (HUVEC) were subcultured on gelatin-coated plates as previously de-

1. Abbreviations used in this paper: ET-1, endothelin-1; L-NNA, $N-\omega-$ nitro-L-arginine; NO, nitric oxide; preproET-1, preproendothelin-1. 


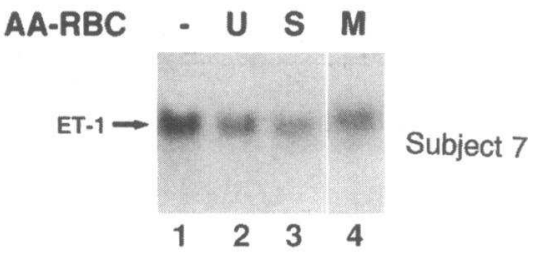

A

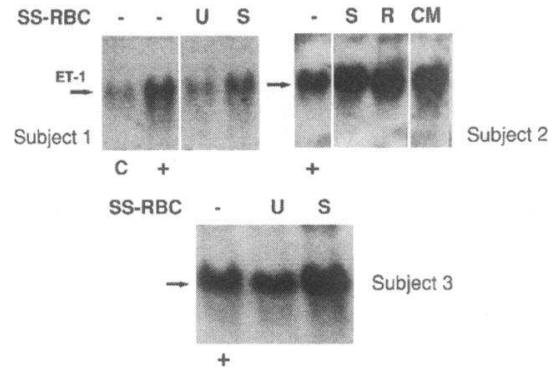

B

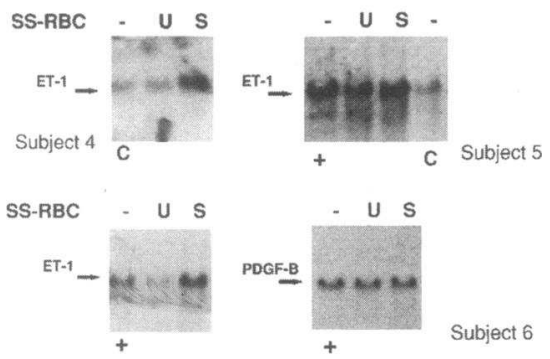

1234

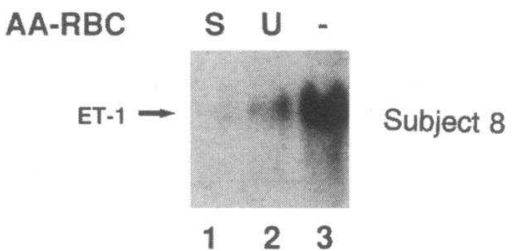

Figure 1. Induction of ET-1 transcripts in endothelial cells after exposure to previously sickled HbSS erythrocytes. ( $A$ and $B$ ) Erythrocytes from six individual subjects were subjected to deoxygenation for 1-3 h $(S)$ or left unsickled $(U)$, and exposed to human umbilical vein endothelial cells (from multiple donors) in culture for $3 \mathrm{~h}$. Parallel plates of endothelial cells were left untreated as controls $(C)$ or were exposed to hypoxia as positive controls ( + ) for the induction of the ET-1 transcript. Total cellular RNA was extracted from the endothelial cells as described. $15 \mu \mathrm{g}$ of RNA/lane was size fractionated on formaldehyde-agarose gels, transferred to nitrocellulose filters, and hybridized with a $\left[{ }^{32} \mathrm{P}\right]$-labeled probe specific for human preproEt-1. The autoradiograms are shown here. The position of the ET-1 transcript is indicated with an arrow. Filters were stripped of probe and rehybridized to a [ $\left.{ }^{32} \mathrm{P}\right]$-labeled probe specific for $\beta$-actin to assure equal loading of RNA (not shown), and these autoradiograms were used for normalization of densitometric scans for quantitation. The filter containing the RNA from subject 6 was stripped again and rehybridized to a $\left.{ }^{32} \mathrm{P}\right]$-labeled probe specific for PDGF-B, and the autoradiogram is shown here. The position of the PDGF-B transcript is indicated. In subject 2 , the medium surrounding the sickle erythrocytes during the sickling process was removed, centrifuged to remove cell membranes and debris, and placed on an endothelial cell monolayer $(C M)$. The erythrocytes were resuspended in fresh medium and placed on the endothelial monolayer $(R)$. RNA from these plates was prepared and analyzed as described above. $C$ displays the results of experiments conducted as described above, but substituting normal $(H b A A)$ erythrocytes for sickle erythrocytes. These erythrocytes were subjected to sickling conditions $(S)$ or left oxygenated $(U)$. Lane 4 from subject 7 contains RNA from a plate of endothelial cells exposed to medium $(M)$ alone which had been exposed to conditions of deoxygenation in parallel to the erythrocytes shown in lane 3 . Lane 1 from subject 7 , and lane 3 from subject 8 , contain RNA from parallel plates of endothelial cells exposed to hypoxia for $3 \mathrm{~h}$. The autoradiograms are shown here.

scribed $(16,17,20,21)$. Endothelial cells at confluence between passages 6 and 10 were exposed to suspensions of red blood cells and kept at $37^{\circ} \mathrm{C}, 5 \% \mathrm{CO}_{2}$ in a humidified incubator. Erythrocytes from subjects with HbSS ("sickle erythrocytes") or normal erythrocytes were collected sterilely from volunteer donors in heparin or citrate, washed twice with PBS, resuspended at a hematocrit of $25 \%$ or $2 \%$ in M199 medium, and exposed to $5 \% \mathrm{CO}_{2} / 95 \% \mathrm{~N}_{2}$ for time periods ranging from $30 \mathrm{~min}$ to $3 \mathrm{~h}$. The cell suspensions were then reoxygenated to $21 \% \mathrm{O}_{2}$ and overlaid on endothelial cell monolayers. The oxygen mixtures were preanalyzed (Northeast Air \& Gas, Inc., Manchester, NH). Probucol (Sigma Chemical Co., St. Louis, MO) was used at a final concentration of 10-20 $\mu \mathrm{M}$. Pyrrolidine dithiocarbamate (PDTC) and $N$-Acetylcysteine (Sigma Chemical Co.) were used at final concentrations of $60 \mu \mathrm{M}$ and $30 \mathrm{mM}$, respectively. Superoxide dismutase and catalase (Sigma Chemical Co.) were used at concentrations of $120 \mathrm{U} / \mathrm{ml}$ and 1,200 U/ $\mathrm{ml}$, respectively. Ghosts of sickle cell membranes were generated by osmotic shock, after washing the erythrocytes thrice in PBS, by resuspending the erythrocyte pellet in 35 vol of "ghost buffer" ( $5 \mathrm{mM}$ Tris$\mathrm{HCl}[\mathrm{pH} \mathrm{7.8}] / 2 \mathrm{mM}$ EDTA), and pelleting at $25,000 \mathrm{~g}$ for $10 \mathrm{~min}$ at $4^{\circ} \mathrm{C}$. Ghosts were carefully separated from the hemoglobin button and washed up to five times in ghost buffer, until no hemoglobin remained, before exposure to human endothelial cell cultures. Free hemoglobin was quantitated with Drabkin's reagent (Sigma Chemical Co.), and read at $530 \mathrm{~nm} . N-\omega$-nitro-L-arginine (L-NNA) was purchased from Sigma Chemical Co. and sodium nitroprusside from Elkins-Sorin, Inc. (Cherry Hill, N.J.), and were used at final concentrations of $1 \mathrm{mM}$ for sodium nitroprusside or $2.5 \mathrm{mM}$ for L-NNA.

RNA analysis. Total cellular RNA was prepared in guanidine from endothelial cells at confluence, untreated or exposed to red blood cells, by centrifugation through a cesium cushion (22). Total RNA (15 $\mu \mathrm{g} /$ lane) was separated by electrophoresis, transferred, and hybridized as previously described $(16,17,20,21)$. The cDNA probes for PDGF-
B, preproET-1, and mouse $\beta$-actin were prepared, labeled, and used in hybridizations as described $(16,17,20,21)$. For quantitation, transcript levels of preproET-1 and PDGF-B were normalized after laser densitometry (Pharmacia LKB Biotechnology, Uppsala, Sweden) to the levels of actin transcripts, which did not change under the various oxygen environment or after exposure to erythrocytes.

mRNA stability. Endothelial cells at confluence were exposed to sickled or unsickled HbSS erythrocytes. Cells were harvested at selected time intervals, treated with actinomycin-D $(5 \mu \mathrm{g} / \mathrm{ml})$, and RNA levels were analyzed and quantitated as described (21).

Measurement of ET-1 peptide. Confluent endothelial cells in 100- or 60-mm plates were washed and exposed to normal, sickled, or unsickled erythrocytes suspended in serum-free medium. The endothelial cellconditioned media were then collected, spun, and filtered to remove cells, concentrated and kept frozen at $-20^{\circ} \mathrm{C}$ until assay. ET-1 peptide was measured using a radioimmunoassay kit (Du Pont, Wilmington, DC) with a detection limit of $10^{-15}$ grams $/ \mathrm{ml}$. The antiserum used in this assay does not cross-react with big endothelin. ET-1 production is shown as ET-1 concentration in $3 \mathrm{ml}$ of medium produced/time.

\section{Results and Discussion}

Exposure of monolayers of human umbilical vein endothelial cells to washed erythrocytes from subjects with sickle cell disease produced no change in the endogenous levels of ET-1 mRNA in the endothelial cells (Fig. $1, A$ and $B$, subjects 1,3 to 6). However, when erythrocytes from the same subjects have been allowed to undergo a cycle of (reversible) sickling by deoxygenation before their exposure to the endothelial cells, a four- to eightfold induction of ET-1 mRNA was consistently 


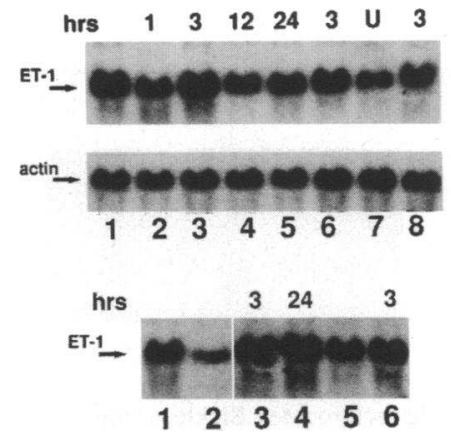

Figure 2. Time course of induction of ET-1 tranA scripts in endothelial cells after exposure to previously sickled sickle erythrocytes. ( $A$ and $C$ ) Erythrocytes from two individual subjects were subjected to deoxygenation for $1 \mathrm{~h}(A$, lane 8$)$

C or $3 \mathrm{~h}$ (all other relevant lanes), or left unsickled $(A$, lane 7$)$, and exposed to human umbilical vein endothelial cells in culture for $1,3,12$, or $24 \mathrm{~h}$, as indicated. Parallel plates of endothelial cells were left untreated as controls $(C$, lane 2$)$ or were exposed to hypoxic conditions as positive controls for the induction of the ET-1 transcript ( $A$, lane 1 and $C$, lane 1 ). In $A$, lane 6 , the medium surrounding the sickle erythrocytes used in lane 3 during the sickling process was removed after the sickling process, centrifuged to remove cell membranes and debris $(100,000 \mathrm{~g}$ for $30 \mathrm{~min})$, and placed on an endothelial cell monolayer. The erythrocytes themselves were resuspended in fresh medium and placed on the endothelial monolayer (lane 3). Preparation of RNA and analysis of transcripts was as described in Fig. 1. The autoradiograms are shown here. The position of the ET-1 transcript is indicated. Filters were stripped of probe and rehybridized to a $\left.{ }^{32} \mathrm{P}\right]$-labeled probe specific for $\beta$-actin to assure equal loading of RNA. $B$ is the actin autoradiogram corresponding to the blot shown in $A$, and these autoradiograms were used for normalization of densitometric scans.

observed at $3 \mathrm{~h}$. Because each subject is unique, and because each set of endothelial cells derived from primary cultures is unique, the range of inductions was large, but reproducible, when the same subject's erythrocytes were retested.

The time courses required for ET-1 transcript induction using erythrocytes from two different subjects are shown in Fig. 2, $A$ and $C$. A modest increase in ET-1 mRNA was regularly seen in endothelial cells after a 1-h exposure to previously sickled sickle erythrocytes, with maximum induction occurring by $3 \mathrm{~h}$ (see also Fig. 1, subject 5). Levels of ET-1 transcript at later times were more variable, with transcript levels falling back to just above baseline by 12 and 24 $\mathrm{h}$ in some cases, despite continued exposure to the sickled erythrocytes (Fig. $2 A$ ).

Although most of the experiments described herein were performed using erythrocytes at a concentration approximating a hematocrit of $21 \%$ ( $\mathrm{vol} / \mathrm{vol}$ ), previously sickled sickle erythrocytes at lower concentrations $(2 \%)$ were sufficient to strongly induce ET-1 (Fig. $2 C$, lane 6). Lower concentrations of erythrocytes were not tested. The length of time during which the sickle erythrocytes were exposed to sickling conditions, ranging from $30 \mathrm{~min}$ (Fig. $1 \mathrm{~B}$, subject 5 ), to $1 \mathrm{~h}$ (Fig. $2 \mathrm{~A}$ ), to $3 \mathrm{~h}$ (used in most of the other experiments shown herein), did not substantially affect their subsequent ability to induce ET-1 transcripts.

The specificity of prepro-ET-1 induction by erythrocytes containing $\mathrm{HbSS}$ was next determined. Normal (HbAA) erythrocytes were collected from a number of donors and treated in parallel fashion to the HbSS erythrocytes. HbAA erythrocytes, whether exposed to hypoxic (sickling-inducing) conditions or not, failed to induce the level of ET-1 transcripts within the endothelial cells (Fig. 1 C).
Our laboratory has previously demonstrated that exposure to hypoxic conditions alone can result in the induction of ET1 in endothelial cells as rapidly as $1 \mathrm{~h}$. It was thus necessary to demonstrate that the effect of the previously sickled erythrocytes on ET-1 gene regulation was not due to an effect of hypoxia alone. A potential role for hypoxia rather than for the sickled erythrocytes in the ET-1 inductions observed here was ruled out in a number of ways. As demonstrated above, normal erythrocytes which had undergone the same exposure to hypoxia as did the sickle erythrocytes had no effect on ET-1 gene expression. The $\mathrm{PO}_{2}$ in the media surrounding the sickled or normal erythrocytes was analyzed and determined to be in the normal range ( $>100$ Torr) before treatment of the endothelial cells. Furthermore, in some experiments, HbSS erythrocytes were resuspended in fresh medium, previously equilibrated with $21 \% \mathrm{O}_{2}$ and $5 \% \mathrm{CO}_{2}$, after undergoing hypoxic sickling, and the $\mathrm{PO}_{2}$ of the media plus erythrocytes was measured and verified to be normoxic before exposure to endothelial cells. The oxygen tension of the medium in which the erythrocytes were suspended in no way correlated with the ability of previously sickled HbSS erythrocytes to induce ET-1. Finally, medium alone (not containing erythrocytes), after undergoing a round of hypoxic exposure, did not affect ET-1 transcript levels when subsequently placed on endothelial cells and incubated for $3 \mathrm{~h}$ at ambient oxygen tensions (Fig. $1 C$, subject 1 ).

The induction of ET-1 transcript by previously sickled HbSS erythrocytes also appeared to be specific at the level of the gene. Other "housekeeping" genes, like actin, were not regulated in response to sickled cells (Fig. $2 B$ ). PDGF-B transcripts, which are induced by hypoxia alone, were not elevated in response to the sickled cells at the time of maximal ET-1 induction (Fig. $1 \mathrm{~A}$, subject 6).

ET-1 transcript stability experiments were performed to determine if the induction of ET-1 by sickled sickle erythrocytes occurs at the level mRNA stabilization. The half-life of the ET-1 transcript was determined during exposure to sickled or unsickled erythrocytes by actinomycin-D chase experiments. The half-life of the ET-1 transcript was $\sim 30$ min under both conditions (data not shown), demonstrating no change in transcript stability.

To determine whether membrane preparations of previously sickled erythrocytes were sufficient to regulate the expression of the ET-1 gene, plasma membrane ghosts of sickled or unsickled sickle erythrocytes were generated and were used to treat endothelial cell cultures. Ghosts made from sickled erythrocytes modestly induced ET-1 transcripts compared to ghosts made from unsickled HbSS erythrocytes (Fig. $3 A$ ). Despite extensive washing however, some hemoglobin invariably remained trapped in ghosts made from sickle erythrocytes after sickling, so that a contribution from this retained protein could not be excluded. Contact between the previously sickled erythrocytes and endothelial cells was not required for induction of ET-1 transcripts. Medium conditioned by sickled erythrocytes during the sickling process induced ET-1 gene expression to the same extent and over the same time course as did the sickled erythrocyte suspension (Fig. $1 \mathrm{~A}$, subject 2 ). Medium conditioned by sickled erythrocytes was subjected to ultracentrifugation $(100,000 \mathrm{~g}$ for $30 \mathrm{~min}$ ) to determine if the factor responsible for the effects on ET-1 gene induction was contained in a membrane particulate or other macromolecular fraction of the medium. Conditioned medium which had been so precleared retained its ability to induce ET-1 transcripts (Fig. $2 A$ ). 
A

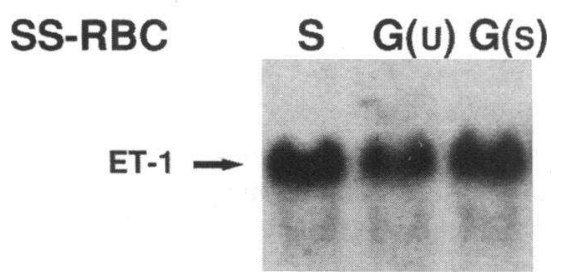

B

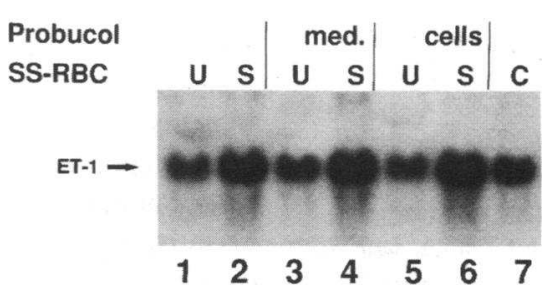

C

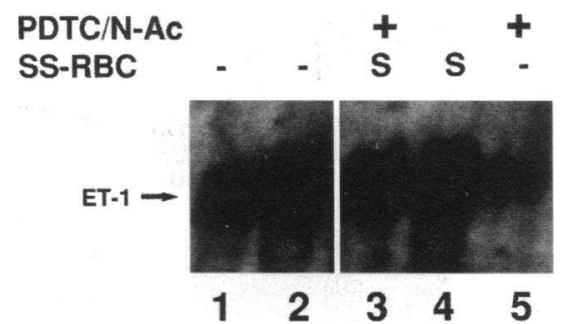

Figure 3. (A) Induction of ET-1 transcripts in endothelial cells after exposure to ghosts from previously sickled sickle erythrocytes. Sickle erythrocytes were subjected to deoxygenation for $3 \mathrm{~h}(S)$ or left unsickled $(U)$, and membrane ghosts $(G)$ were prepared from some of the sickled [ $G(S)$ ] and unsickled $[G(U)]$ erythrocytes, and cells or ghosts were exposed to human umbilical vein endothelial cells in culture for $3 \mathrm{~h}$. (B) The free radical chelator probucol does not inhibit ET-1 transcript induction by sickled sickle erythrocytes. Sickle erythrocytes were subjected to deoxygenation for $3 \mathrm{~h}(S)$ (lanes 2, 4,6) or left unsickled $(U)$ (lanes $1,3,5$ ). Probucol was added to medium (med.) surrounding the erythrocytes in lanes 3 and 4 before exposure of the cells to the endothelial cells. The endothelial cell monolayers used in lanes 5 and 6 were incubated in the presence of probucol (cells) for $8 \mathrm{~h}$ before exposure to sickled or unsickled erythrocytes. A parallel plate of endothelial cells was left untreated as a control (lane 7). ( $C$ ) Lowering the intracellular redox state inhibits basal and sickled erythrocyte induction levels of ET-1 transcripts. Sickle erythrocytes were subjected to sickling by deoxygenation for $3 \mathrm{~h}(S)$ (lanes 3 and 4). Parallel plates of endothelial cells served as controls (lane 1 and 5 ), or were exposed to $3 \mathrm{~h}$ of hypoxia as a positive control (lane 2). Pyrrolidine dithiocarbonate and $N$-acetylcysteine were added to the plates used for lanes 3 and 5. Preparation of RNA and analysis of transcripts was as described in Fig. 1. The autoradiograms are shown here. The position of the ET-1 transcript is indicated. Filters were stripped of probe and rehybridized to a $\left[{ }^{32} \mathrm{P}\right]$-labeled probe specific for $\beta$-actin to assure equal loading of RNA (autoradiograms not shown) and these autoradiograms were used for normalization of densitometric scans.

The finding that physical contact of the erythrocyte with the endothelial cell is not required for regulation of the ET-1 gene suggested a number of possibilities regarding mechanisms. The results of the conditioned medium experiments make it likely that a soluble factor is elaborated by the erythrocytes during (and for a period subsequent to) the sickling process. Free radical generation, including excessive formation of hydroxyl radicals in $\mathrm{HbSS}$ erythrocytes $(23,24)$, induced by spontaneous autooxidation of the iron in sickle heme (25), could theoretically affect the endothelial cell at a distance. Treatment of sickled sickle cell-conditioned medium with superoxide dismutase to eliminate hydroxyl radicals did not ablate the ability of the medium to induce ET-1 transcripts (data not shown). The free radical scavenger probucol $(26,27)$ was also used to determine if free radical generation may play a role in ET-1 gene regulation. The presence of probucol in the medium containing the sickled or unsickled erythrocytes had no effect on their ability to induce ET-1 transcripts (Fig. $3 \mathrm{~A}$ ). Similarly, pretreatment of the endothelial cells with probucol to allow intracellular accumulation of the free radical scavenger did not affect ET-1 transcript basal levels or induction by sickled erythrocytes. Potential effects of the sickled cells on the redox potential of the endothelial cells was studied by pretreatment of the endothelial cells with the reducing agents pyrrolidine dithiocarbomate and $\mathrm{N}$ acetyl cysteine before exposure to sickled erythrocytes. These reducing agents had only a modest effect on reducing the induction of ET-1 transcripts by sickled sickle erythrocytes (24$36 \%$ decreases by densitometry). However, these agents also lowered the constitutive level of ET-1 transcripts in the control cells, presumably by lowering the basal oxidation state of the cells (Fig. $3 C$ ). It was therefore not possible to determine if the effects on the sickled erythrocyte induction were specific for the induction or were secondary to a lowering of the basal expression. This result also suggests that basal control of ET1 transcript levels in endothelial cells, at least in culture, is dependent on the redox state of the cells. It may be noteworthy that basal levels of ET-1 expression in endothelial cells has been linked to the transcription factor AP-1 (28), and reducing conditions are known to activate AP-1 DNA-binding (29-31, 31a). These findings raise interesting speculation regarding the regulation of ET-1 during pathological states such as ischemiareperfusion and reoxygenation injury, where striking changes in the oxidation state of affected cells have been reported.

We have previously demonstrated that the endogenous production of nitric oxide (NO) by endothelial cells in culture affects the transcription of the ET-1 gene, with inhibitors of intracellular NO production resulting in increases in ET-1 transcript levels, independent of $\mathrm{PO}_{2}(16)$. A potential role for NO in mediating the response of endothelial cells to sickled sickle cells was explored through the use of agents which serve as nitric oxide donors ( sodium nitroprusside, SNP), or conversely, which block endogenous production of NO by endothelial cells (the arginine analogue L-NNA). Elevation of local NO levels by SNP treatment inhibited both basal expression and sickled cell-induced expression of ET-1 transcripts (Fig. $4 A$ ), suggesting that NO might mediate the regulation of ET-1 by sickled erythrocytes. If such a mechanism were operative, it should follow that alterations in the endogenous production of NO by endothelial cells should similarly alter the ability of sickled erythrocytes to regulate ET-1 levels. As predicted, blockade of endogenous NO production by pretreatment with L-NNA resulted in a three to fourfold induction of ET-1 transcripts, and exposure to sickled erythrocytes produced no further induction of ET-1 transcripts (Fig. $4 \mathrm{~B}$ ).

ET-1 peptide levels in medium overlying endothelial cells exposed to previously sickled or unsickled sickle erythrocytes was measured by a sensitive radioimmunoassay. ET-1 peptide levels rose by two to threefold over the $3 \mathrm{~h}$ of exposure to sickled erythrocytes (Table I).

It is likely that imbalances in vascular tone, manifested by local vasospasm or failure of vasodilatory mechanisms, contribute to sickle cell crises and organ damage (32). There is abundant evidence that control of local vascular tone is abnormal not only during sickle cell crises, but also in the steady state 
A

SNP Inhibits ET-1 Induction by Sickled RBC

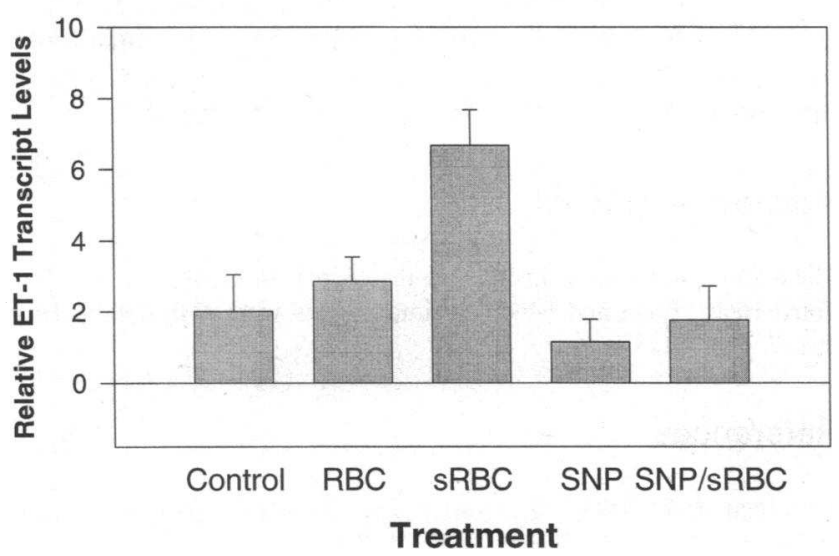

B

ET-1 Induction by L-NNA and Sickled RBC

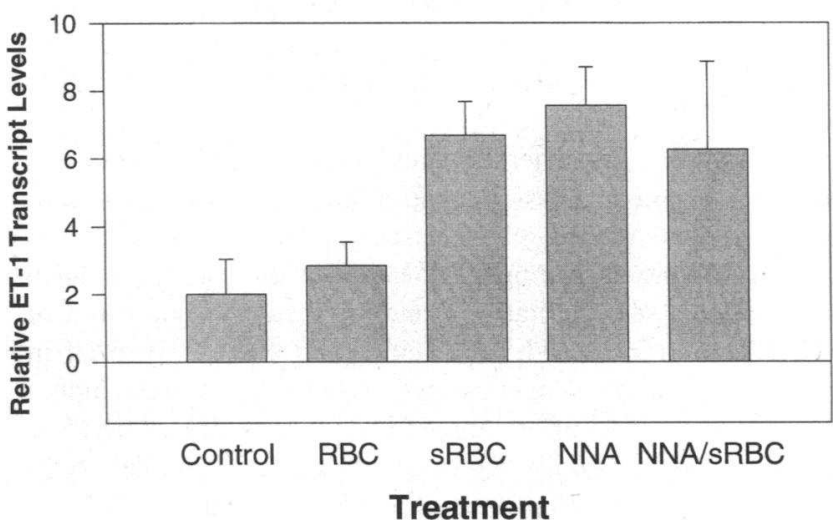

Figure 4. NO donors and inhibitors of NO synthesis prevent induction of the ET-1 gene by sickled sickle erythrocytes. Endothelial cells at confluence were exposed for $12 \mathrm{~h}$ to $1 \mathrm{mM}$ sodium nitroprusside $(S N P)(A)$, or to $2.5 \mathrm{mM} \mathrm{L}-N N A(N N A)(B)$, or left untreated. Sickle erythrocytes were left untreated $(R B C)$, or subjected to deoxygenation for $3 \mathrm{~h}(s R B C)$, and overlaid on the endothelial cells for $3 \mathrm{~h}$. Total RNA was isolated, separated by electrophoresis, hybridized with a radiolabeled probe for preproET-1, subjected to autoradiography, stripped of probe, and rehybridized to a radiolabeled probe for $\beta$-actin for purposes of normalization. The relative mRNA levels for preproET- 1 normalized to $\beta$-actin mRNA are shown for the various conditions. In $A$, treatment with SRBC was statistically different from all other conditions which were not different from one another. In $B$, treatments with $\mathrm{SRBC}, \mathrm{L}-N N A$, and $\mathrm{L}-N N A+\mathrm{sRBC}$ were statistically different from other conditions, and were not different from one another.

course of the disease. Abnormalities in microvascular flow, including frequent episodes of stasis or intermittent flow, and large local oscillations in periodic microcirculatory flow with synchronization of rhythmic flow in large domains of microvessels, have also been demonstrated in subjects with sickle cell disease (33-35). These observations of disturbances in microvascular flow have been interpreted as being due to intermittent

Table I. Sickled HbSS Erythrocytes Induce ET-1 Secretion from Cultured Endothelial Cells

\begin{tabular}{clc}
\hline Experiment & \multicolumn{1}{c}{ Condition } & ET-1 production \\
\hline \multirow{2}{*}{1} & & $p M$ \\
& Control & 5.0 \\
& AA-RBC & 5.7 \\
& SS-RBC & 6.9 \\
2 & Sickled SS-RBC & 28.4 \\
& Control & 7.2 \\
& AA-RBC & 6.4 \\
& SS-RBC & 4.9 \\
& Sickled SS-RBC & 33.8
\end{tabular}

Media were conditioned by endothelial cells for $6 \mathrm{~h}$ under control conditions (Control), with untreated erythrocytes from HbAA or HbSS subjects ( $A A-R B C$ and $S S-R B C$, respectively) or HbSS erythrocytes which had undergone a round of sickling (Sickled SS-RBC). Sickle and normal erythrocytes were obtained from different donors for experiment 1 and experiment 2 . The total amount of ET-1 secreted was quantified with a radioimmunoassay and normalized to total cellular protein/plate. Equal amounts of total cellular protein per plate were obtained under all conditions tested. Recovery of ET-1 was $\geq 90 \%$. Inter- and intraassay variabilities were 12 and $6 \%$, respectively. ET-1 production is shown as ET-1 concentration $(p M)$ in $3 \mathrm{ml}$ of medium produced $/ 6 \mathrm{~h}$. occlusions by sickled erythrocytes. Alternatively, however, they may represent local instability of vascular tone and unbalanced regulatory and compensation mechanisms. Altered vascular reactivity in response to pressor stimuli has also been demonstrated in sickle cell disease (36). More recently, sickle erythrocytes have been found to interfere with endothelium-dependent vasorelaxation, possibly by inhibition of endothelial-derived relaxing factor (NO) (37). Yet, the mechanisms responsible for altered endothelial regulation of vasoreactivity in the pathogenesis of vasoocclusive events in sickle cell anemia remain unknown (see references 32, 38 for review).

A number of specific local vasoregulatory mechanisms are likely to be indirectly activated or aberrantly regulated in sickle cell disease, contributing to the abnormal control of vascular tone. Various conditions contribute to the increased vascular wall shear forces observed in sickle cell disease, including the higher viscosity of blood from subjects with sickle cell disease (39) and the increased blood flow rates secondary to the severe anemia and low systemic vascular resistance. Discrepant, tissuespecific vasomotor effects may be mediated by changes in the balance of shear-induced endothelial cell production of vasoconstrictor peptides, like ET-1 and PDGF-BB (40-45), and shear-induced production of vasodilators like nitric oxide (4650 ), and prostacyclins (51). Tissue hypoxia is common in subjects with sickle cell disease and may also contribute to local vasoconstriction. In a model of the vasoocclusive processes which occur in sickle cell anemia, the very first event that occurred was local tissue hypoxia, before any vasoocclusion, obstruction, or adhesion. Subsequently, precapillary obstruction, adhesion in postcapillary venules, and secondary trapping of erythrocytes is observed $(52,53)$. Our previous work has demonstrated that endothelial cells respond to decreases in oxygen tension by transcriptional induction of genes encoding the potent vasoconstrictors ET-1 and PDGF-B $(16,17,21)$.

The aforementioned potential effects of sickle cell disease 
on local vessel dynamics are all indirect. This report is the first demonstration that sickle erythrocytes may have the potential capacity to affect local vasomotor tone directly. Sickle erythrocytes, after sickling, alter gene expression in endothelial cells in culture, whereas unsickled erythrocytes have no such effect. Transcripts for the powerful vasoconstrictor ET-1 are significantly and rapidly increased upon exposure to sickled erythrocytes.

The mechanism whereby previously sickled erythrocytes can regulate gene expression in the endothelium is under investigation. We have ruled out an effect of hypoxia itself in this process. The membrane lipids of sickle erythrocytes have been shown to change quantitatively and qualitatively as a result of the sickling process $(54,55)$, and lipids are widely used in nature as second messengers in pathways leading to gene induction. The generation of membrane ghosts from sickled erythrocytes did at least partially reproduce the effect of sickled erythrocytes. The generation of free radicals in the course of sickling and reoxygenation does not appear to play a major role in the induction of ET-1 by sickled cells.

One mechanism for control of ET-1 gene expression by sickled erythrocytes appears to involve the vasodilatory and intracellular signaling molecule NO. We have previously demonstrated that the endogenous production of NO by endothelial cells in culture affects the transcription of the ET-1 gene, with inhibitors of intracellular NO production resulting in increases in ET-1 transcript levels, independent of $\mathrm{PO}_{2}(16)$. We demonstrate here that external manipulation of NO production by endothelial cells, whether by blocking its production with an arginine analogue (L-NNA), or supplying NO exogenously via a NO donor (sodium nitroprusside), abrogates the ability of sickled sickle erythrocytes to modulate ET-1 production, thus implicating NO in the regulation of endothelial cell gene expression by sickled cells. How changes in intracellular NO production induced by sickled erythrocytes may contribute to the induction of ET-1 by these erythrocytes is currently under investigation. The possibility that free hemoglobin, released during the sickling process, might chelate NO and reduce local (extracellular) levels, thereby inducing ET-1 transcription (16), was ruled out in a number of ways: $(a)$ levels of free hemoglobin in the media surrounding HbSS erythrocytes after sickling, as measured using Drabkin's reagent, did not differ from the levels released by HbAA erythrocytes (data not shown), yet only the HbSS erythrocytes induced ET-1 expression; $(b)$ washing of the erythrocytes after they had undergone a round of sickling did not prevent induction of ET-1 (see Fig. 2 A, lane 3); (c) hemoglobin-free membrane ghosts reproduced the induction of ET-1 (Fig. $3 A$ ). It has been postulated that the free radicals generated by sickle cells during the sickling process would deplete local NO production (see reference 32 ). Furthermore, we have recently discovered that exposure of endothelial cells to sickled erythrocytes results in profound suppression of the transcript for the endothelial cell (constitutive) nitric oxide synthase (Phelan, M., and D.V. Faller, manuscript submitted for publication ).

The relevance of these findings to the pathophysiology of sickle cell disease remain to be determined. The in vitro studies described herein have established that exposure of endothelium to sickled sickle erythrocytes results in elevations in ET-1 transcripts and protein. Elevations in circulating levels of ET-1 have been reported in subjects with sickle cell disease $(18,19)$. Since the concentration of ET-1 is likely to be much higher at the interface of endothelium and smooth muscle than in the larger volume of distribution of the circulating blood, the local production of ET-1 in the microvasculature in sickle cell disease may actually be significantly higher than the values obtained from plasma. The ongoing development of ET-1 antagonists or ET1 receptor blockers as therapeutics will permit determination of the role of endothelial cell gene regulation by sickled cells in the course of steady state or acute sickle cell disease.

\section{Acknowledgments}

The authors gratefully acknowledge the support of grants from the National Heart, Lung and Blood Institute in this work (HL-45940, HL15157, HL-37118).

\section{References}

1. Diggs, L. W., and C. F. V. Bruegge. 1954. Vascular occlusive mechanisms in sickle cell disease. J. Am. Med. Assoc. 46:46-49.

2. Konotey-Ahulu, F. I. D. 1974. The sickle cell diseases: clinical manifestations including the "sickle crisis." Arch. Intern. Med. 133:611-619.

3. Boros, L., C. Thomas, and W. J. Weiner. 1976. Large cerebral vessel disease in sickle cell anaemia. J. Neurol. Neurosurg. Psychiatry. 39:1236-1239.

4. Merkel, K. H. H., P. L. Ginsberg, J. C. Parker, and M. J. D. Post. 1978. Cerebrovascular disease in sickle cell anemia: a clinical, pathological and radiological correlation. Stroke. 9:45-52.

5. Stockman, J. A., M. A. Nigro, M. M. Mishkin, and F. A. Oski. 1972. Occlusion of large cerebral vessels in sickle-cell anemia. N. Engl. J. Med. 287:846-849.

6. Hoover, R., R. Rubin, G. Wise, and R. Warren. 1979. Adhesion of normal and sickle erythrocytes to endothelial monolayer cultures. Blood. 54:872-876.

7. Hebbel, R. P., O. Yamada, C. F. Moldow, H. S. Jacobs, J. G. White, and J. W. Eaton. 1980. Abnormal adherence of sickle erythrocytes to cultured vascular endothelium. Possible mechanism for microvascular occlusion in sickle cell disease. J. Clin. Invest. 65:154-160.

8. Hebbel, R. P., A. B. Boogaerts, J. W. Eaton, and M. H. Steinberg. 1980. Erythrocyte adherence to endothelium in sickle-cell anemia. A possible determinant of disease severity. N. Engl. J. Med. 302:992-995.

9. Wautier, J. L., D. Pintigny, and J. Maclouf. 1986. Release of prostacyclin after erythrocyte adhesion to cultured vascular endothelium. J. Lab. Clin. Med. 107:210-215.

10. Weinstein, R., M. A. Zhou, A, Bartlett-Pandite, and K. Wenc. 1990. Sickle erythrocytes inhibit human endothelial cell DNA synthesis. Blood. 76:2146-2152.

11. Vane, J. R., E. E. Anggard, and R. M. Botting. 1990. Mechanisms of disease: regulatory functions of the vascular endothelium. N. Engl. J. Med. 323:27-36.

12. Yanagisawa, M., H. Kurihara, S. Kimura, Y. Tomobe, M. Kobayashi, Y. Mitsui, Y. Yazaki, G. Katsutoshi, and T. Masaki. 1988. A novel potent vasoconstrictor peptide produced by vascular endothelial cells. Nature (Lond.). 332:411415 .

13. MacCumber, M. W., C. A. Ross, B. M. Glaser, and S. H. Snyder. 1989. Endothelin: visualization of mRNAs by situ hybridization provides evidence for local action. Proc. Natl. Acad. Sci. USA. 86:7285-7289.

14. Moon, D. G., M. A. Horgan, T. T. Anderson, S. R. Krystek, J. W. Fenton, and A. B. Malik. 1989. Endothelin-like pulmonary vasoconstrictor peptide release by alpha-thrombin. Proc. Natl. Acad. Sci. USA. 86:9529-9533.

15. Milner, P., P. Bodin, A. Loesch, and G. Burnstock. 1990. Rapid release of endothelin and ATP from isolated aortic endothelial cells exposed to increased flow. Biochem. Biophys. Res. Commun. 170:649-656.

16. Kourembanas, S., L. P. Mcquillan, G. K. Leung, and D. V. Faller. 1993. Nitric oxide regulates the expression of vasoconstrictors and growth factors by vascular endothelium under both normoxia and hypoxia. J. Clin. Invest. 92:99104.

17. Kourembanas, S., P. A. Marsden, L. P. Mcquillan, and D. V. Faller. 1991. Hypoxia induces endothelin gene expression and secretion in cultured human endothelium. J. Clin. Invest. 88:1054-1057.

18. Rybicki, A. C., S. Musto, G. L. Swinson, L. J. Benjamin, R. L. Nagel, and R. S. Schwartz. 1991. Increased levels of endothelin-1 in plasma of sickle cell anemia patients. Blood. 78:202a. (Abstr.)

19. Longenecker, G., D. Culbertson, B. Beyers, E. Manci, and V. Mankad. 1991. Plasma endothelin (ET) levels are elevated in sickle cell disease (SCD). Blood. 78:1645a. (Abstr.)

20. Kourembanas, S., and D. V. Faller. 1989. Platelet-derived growth factor production by human umbilical vein endothelial cells is regulated by basic fibroblast growth factor. J. Biol. Chem. 264:4456-4459.

21. Kourembanas, S., R. Hannan, and D. V. Faller. 1990. Oxygen tension 
regulates the expression of platelet-derived growth factor-B chain gene in human endothelial cells. J. Clin. Invest. 86:670-674.

22. Chirgwin, J. M., A. E. Przybyla, R. J. MacDonald, and W. J. Rutter 1979. Isolation of biologically active ribonucleic acid from sources enriched in ribonuclease. Biochemistry. 18:5294-5299.

23. Hebbel, R. P., J. W. Eaton, M. Balasingam, and M. H. Steinberg. 1982. Spontaneous oxygen radical generation by sickle erythrocytes. J. Clin. Invest. 70:1253-1259.

24. Schacter, L. P. 1986. Generation of superoxide anion and hydrogen peroxide by erythrocytes from individuals with sickle trait or normal haemoglobin. $J$. Clin. Invest. 16:204-210.

25. Hebbel, R. P., W. T. Morgan, J. W. Eaton, and B. E. Hedlund. 1988. Accelerated autoxidation and heme loss due to instability of sickle hemoglobin. Proc. Natl. Acad. Sci. USA. 85:237-241.

26. Tajika, T., K. Ono, Y. Kyo, Y. Ono, and M. Miura. 1993. The effect of probucol on the proliferation of cultured human umbilical vascular endothelial cells. In Vitro Cell. Dev. Biol. Anim. 29A:347-349.

27. Tesfamariam, B., and R. A. Cohen. 1992. Free radicals mediate endothelial cell dysfunction caused by elevated glucose. Am. J. Physiol. 263:H321-H326.

28. Lee, M., M. S. Dhadly, D. H. Temizer, J. A. Clifford, M. Yoshizumi, and T. Quertermous. 1991. Regulation of endothelin-1 gene expression by $f o s$ and jun. J. Biol. Chem. 266:19034-19039.

29. Meyer, M., H. L. Pahl, and P. A. Baeuerle. 1994. Regulation of the transcription factors NF-kappa B and AP-1 by redox changes. Chem. Biol. Interact. 91:91-100.

30. Schenk, H., M. Klein, W. Erdbrugger, W. Droge, and K. Schulze-Osthoff. 1994. Distinct effects of thioredoxin and antioxidants on the activation of transcription factors NF- $B$ and AP-1. Proc. Natl. Acad. Sci. USA. 91:1672-1676.

31. Weng, H., S. -Y. Choi, and D. V. Faller. 1995. The Moloney leukemia retroviral long terminal repeat trans-activates AP-1-inducible genes and AP-1 transcription factor binding. J. Biol. Chem. In press.

31a. Bhandopadhyay, R., M. Phelan, and D. V. Faller. 1995. Biochem. Biophys. Acta. In press.

32. Faller, D. V. 1994. Vascular modulation in sickle cell anemia. In Sickle Cell Disease: Basic Principles and Clinical Practice. S. H. Embury, R. P. Hebbel, N. Mohandas, and M. H. Steinberg, editors. Raven Press, Ltd., New York. 235246.

33. Kennedy, A. P., B. Williams, E. F. Meydrech, and M. H. Steinberg. 1988 Regional and temporal variation in oscillatory blood flow in sickle cell disease Am. J. Hematol. 28:92-94.

34. Rodgers, G. P., A. N. Schechter, C. T. Noguchi, H. G. Klein, A. W. Neinhuis, and R. F. Bonner. 1984. Periodic microcirculatory flow in patients with sickle-cell disease. N. Engl. J. Med. 311:1534-1538.

35. Lipowsky, H. H., N. U. Sheikh, and D. M. Katz. 1987. Intravital microscopy of capillary hemodynamics in sickle cell disease. J. Clin. Invest. 80:117127.

36. Hatch, F. E., L. R. Crowe, D. E. Miles, J. P. Young, and A. Portner. 1989. Altered vascular reactivity in sickle hemoglobinopathy. A possible protective factor from hypertension. Am. J. Hypertens. 2:2-8.

37. Mosseri, M., A. N. Bartlettpandite, K. Wenc, J. M. Isner, and R. Weinstein. 1993. Inhibition of endothelium-dependent vasorelaxation by sickle erythrocytes. Am. Heart J. 126:338-346.

38. Hebbel, R. P. 1991. Beyond hemoglobin polymerization: the red blood cell membrane and sickle disease pathology. Blood. 77:214-237.

39. Kaul, D. K., S. Baez, and R. L. Nagel. 1991. Flow properties of oxygenated $\mathrm{HbS}$ and $\mathrm{HbC}$ erythrocytes in the isolated microvasculature of the rat. A contribution to the hemorheology of hemoglobinopathies. Clin. Hemorheol. 1:73-86.
40. Milner, P., P. Bodin, A. Loesch, and G. Burnstock. 1992. Increased shear stress leads to differential release of endothelin and ATP from isolated endothelial cells from 4-month-old and 12-month-old male rabbit aorta. J. Vasc. Res. 29:420425.

41. Kuchan, M. J., and J. A. Frangos. 1993. Shear stress regulates endothelin1 release via protein kinase-C and cGMP in cultured endothelial cells. Am. J. Physiol. 264:H150-H156.

42. Malek, A. M., A. L. Greene, and S. Izumo. 1993. Regulation of endothelin1 gene by fluid shear stress is transcriptionally mediated and independent of protein kinase-C and cAMP. Proc. Natl. Acad. Sci. USA. 90:5999-6003.

43. Mitsumata, M., R. S. Fishel, R. M. Nerem, R. W. Alexander, and B. C.

Berk. 1993. Fluid shear stress stimulates platelet-derived growth factor expression in endothelial cells. Am. J. Physiol. 265:H3-H8.

44. Morita, T., H. Kurihara, K. Maemura, M. Yoshizumi, and Y. Yazaki. 1993. Disruption of cytoskeletal structures mediates shear stress induced endothelin-1 gene expression in cultured porcine aortic endothelial cells. J. Clin. Invest. 92:1706-1712.

45. Malek, A. M., G. H. Gibbons, V. J. Dzau, and S. Izumo. 1993. Fluid shear stress differentially modulates expression of genes encoding basic fibroblast growth factor and platelet-derived growth factor-B chain in vascular endothelium. J. Clin. Invest. 92:2013-2021.

46. Hakim, T. S. 1994. Flow-induced release of EDRF in the pulmonary vasculature: site of release and action. Am. J. Physiol. 267:H363-H369.

47. Miller, V. M., and J. C. Burnett. 1992. Modulation of NO and endothelin by chronic increases in blood flow in canine femoral arteries. Am. J. Physiol. 263:H103-H108.

48. Cooke, J. P., E. Rossitch, Jr., N. A. Andon, J. Loscalzo, and V. J. Dzau. 1991. Flow activates an endothelial potassium channel to release an endogenous nitrovasodilator. J. Clin. Invest. 88:1663-1671.

49. Pohl, U., K. Herlan, A. Huang, and E. Bassenge. 1991. EDRF-mediated shear-induced dilation opposes myogenic vasoconstriction in small rabbit arteries. Am. Physiol. Soc. H2016-H2023.

50. Nishida, K., D. G. Harrison, J. P. Navas, A. A. Fisher, S. P. Dockery, M. Uematsu, R. M. Nerem, R. W. Alexander, and T. J. Murphy. 1992. Molecular cloning and characterization of the constitutive bovine aortic endothelial cell nitric oxide synthase. J. Clin. Invest. 90:2092-2096.

51. Frangos, J. A., S. G. Eskin, L. V. McIntire, and C. L. Ives. 1985. Flow effects on prostacyclin production by cultured human endothelial cells. Science (Wash. DC). 227:1477-1479.

52. Kaul, D. K., M. E. Fabry, and R. L. Nagel. 1989. Microvascular sites and characteristics of sickle cell adhesion to vascular endothelium in shear flow conditions: pathophysiological implications. Proc. Natl. Acad. Sci. USA. 86:33563360 .

53. Fabry, M. E., V. Rajanayagam, E. Fine, S. Holland, J. C. Gore, R. L. Nagel, and D. K. Kaul. 1989. Modeling sickle cell vasoocclusion in the rat leg: Quantification of trapped sickle cells and correlation with 31-P metabolic and 1-H magnetic resonance imaging changes. Proc. Natl. Acad. Sci. USA. 86:38083812.

54. Lubin, B., D. Chiu, J. Bastacky, B. Roelofsen, and L. L. M. van Deenen 1981. Abnormalities in membrane phospholipid organization in sickled erythrocytes. J. Clin. Invest. 67:1643-1650.

55. Middelkoop, E., B. H. Lubin, E. M. Beevers, J. A. P. Op den Kamp, P. Comfurius, D. Chiu, R. F. A. Zwaal, L. L. M. van Deenen, and B. Roelofsen. 1988 Studies on sickled erythrocytes provide evidence that the assymetric distribution of phosphatidylserine in the red cell membrane is maintained by both ATP-dependent translocation and interaction with membrane skeletal proteins. Biochim. Biophys. Acta. 937:281-286. 